\title{
The Role of Fossil Fuel (Oil and Gas) in the World Geopolitics of Energy (Case Study of Iran 2000-2015)
}

\author{
Azam Pourghasemi ${ }^{*}$ and Mohammad Akhbari² \\ 'Department of Political Geography, Central Tehran Branch, Islamic Azad University, Tehran, Iran; \\ a.pourghasemi@hotmail.com \\ ${ }^{2}$ Department of Geography, Central Tehran Branch, Islamic Azad University, Tehran, Iran
}

\begin{abstract}
The energy plays a significant role in human life and almost it is not possible to continue the life without it. This is why energy has got a key role in our national and international policies and has shaped up patterns of rivalry, cooperation, conflict, violation, interaction, convergence, and divergence in the international arena and relations between countries and authorities. So, interestingly the sources of energy provision, energy corridors, consumer markets, energy trade, energy technology, and things like them increase in value. This study investigated energy resources in Iran and Middle East in library research method. In addition to have a unique geopolitical position, Iran is located in ellipse of energy and there is more than 70 percent of world resources of oil and 60 percent of world resources of gas in Iran. Also, Iran has located in the energy corridor of north to south and east to west and all of the ways pass through this wide country. Hence, it can pump money into the country not only by selling energy, but also with transmitting of energy and accordingly, it can evolve the country economy with a correct planning and engagement with countries.
\end{abstract}

Keywords: Energy, Fossil Fuel, World Geopolitics

\section{Introduction}

Nowadays, if the global system is considered a unit body, Islamic Republic of Iran is taken as its heart geopolitically ${ }^{1,2}$. At the opposite end of spectrum, United States has tried to be the brain of this body over a half century. Moreover, at the same time with Islamic revolution in Iran and Soviet Union collapse and also by emerging bipolar system of pantheism-humanism, Iran position of the center of pantheism is strengthening Islamic Revolution in Islam world particularly in the area of being a pattern for getting rid of foreign dominance which indicates geopolitical position of Iran among regional countries especially Middle East ${ }^{3,4}$.

Globally, the importance of geopolitical position of Iran has been expressed as if it is heart land of $21^{\text {th }}$ century geopolitics and is located in the heart of strategic ellipsoidal area of energy. It is in a way that every change in geopolitical circumstances of Iran will doom geopolitical circumstance of the region and it will result in bad geostrategic consequences globally, $y^{5,67}$.

The thing that we are following in this work is that what role are fossil energies playing in global geopolitics and Iran and what is its impact in rising Iran position of power in the region. Also, situation and abilities of Iranian energy will be studied in comparison with other countries which have energy. It can answer this question that does locating Iran in the center of energy ellipse have any impact on power improvement and bargaining power of Iran?

\section{Studying Some Concepts}

Fossil energies: these energies are coal, oil and gas which industrial revolution owes its existence to these energies ${ }^{8}$.

\subsection{Power}

It is a set of material and spiritual factors which make one person or a group of people obey one person or a group of people.

\subsection{Geostrategic Area}

This area is a special indication of actions and reaction in a wide part of the world. Geopolitical areas are two political semispheres which everyone was under the control of one superpower on the earth (in the last system it was dipole).

${ }^{*}$ Author for correspondence 


\subsection{Geopolitical Area}

It is created based on an area or congruent geographical space with a structure of performance. Emerging geopolitical area requires the region and its elements to get pregnant. On the other hand, if structural or functional elements of a geographical area play their role well individually or socially and/or complete or incomplete and in the political aspect. Therefore, geographical are turns to be a geopolitical area?.

\section{Investigation of Supply and Demand History of Energy in the World}

In 1970s conflicts, global demand for oil was reduced by global recession resulting from the conflicts and it resolved the conflict with technology improvement, cost reduction, and increasing productivity in two sides of supply and demand. In 1985, when the price fell, OPEC had 15 million barrels per day extra production of oil in hand which was equivalent to 59 percent of production capacity of these countries and 25 percent of the world ${ }^{10}$. In 1990, the extra capacity of production was 5 to 5.5 million barrel per day which included 20 percent of OPEC production capacity and 8 percent of global demand. This amount of excess production could control fluctuations in oil supply and manage oil conflicts. United States brought energy to political issues with some countries because of unreal assurance of price stability and having no national comprehensive policy of energy, and it put restrictions on production increase. Simultaneously, prediction of investment in energy sector which was imagined to be encouraged by market mechanisms, were not achieved and excess production began to decrease ${ }^{11}$. In 2001, excess production capacity of OPEC reduced to 20 percent of global demand due to fail in achieving to predicted investment in exploration and production of oil that this lach of excess production capacity continues. The most important factor in deciding oil price in the market is the issue of lacking in excess oil production capacity.

\section{Persian Gulf Position in Global Energy}

I the present century, world is divided into six parts according to playing economical role in which every region that is not included in this division does not have significant importance. These regions are: 1. North America, 2. Western Europe, 3. Middle East (Persian Gulf), 4. Southeast Asia, 5. MoscowLeningrad axis, and 6. India. 4 regions of these 6 regions export their production to other countries and have enormous production. It is only one area which exports crude materials and it is Middle East ${ }^{12}$.

There is a special situation about concentration of global gas resources in the Middle East region in which 40 percent of global gas resource storages are placed in these regions. Based on the predictions, daily production of oil in Middle East has reached 26 million barrel per day in 2010 and in 2020, it will increase by 6 million barrel per day to hit 35 million barrels per day; hence, shares of this region in global oil production will grow from 27 percent to 33 percent in 2020 (International Energy Outlook, 2004).

Table 1. The amount of reserves, production and consumption of oil in the Persian Gulf countries

\begin{tabular}{|l|c|c|c|c|}
\hline Country & Billion barrels & Percent of Total & $\begin{array}{c}\text { Production (thousand barrels } \\
\text { per day) }\end{array}$ & $\begin{array}{c}\text { Consumption } \\
\text { (thousand barrels per day) }\end{array}$ \\
\hline Saudi Arabia & 264.1 & 21.0 & 10846 & 2224 \\
\hline Iran & 137.6 & 10.9 & 4325 & 1730 \\
\hline Iraq & 115.0 & 9.1 & 2423 & - \\
\hline Kuwait & 101.5 & 8.1 & 2784 & 300 \\
\hline United Arab Emirates & 97.8 & 7.8 & 2980 & 467 \\
\hline Qatar & 27.3 & 2.2 & 1378 & - \\
\hline Oman & 5.6 & 0.4 & 728 & 4825 \\
\hline Total area of Middle East & 748.9 & 59.5 & 25464 & - \\
\hline
\end{tabular}

Table 2. The amount of reserves, production and consumption of gas in Persian Gulf countries. End of 2008

\begin{tabular}{|l|c|c|c|c|}
\hline Country & Trillion cubic meter & Percent & Production (billion cubic meter) & Consumption (billion cubic meter) \\
\hline Saudi Arabia & 7.57 & 4.1 & 78.1 & 78.1 \\
\hline Iran & 29.61 & 116.0 & 116.3 & 117.6 \\
\hline Iraq & 3.17 & 1.7 & - & - \\
\hline Kuwait & 1.78 & 1 & 12.8 & 12.8 \\
\hline
\end{tabular}




\begin{tabular}{|l|c|c|c|c|}
\hline Country & Trillion cubic meter & Percent & Production (billion cubic meter) & Consumption (billion cubic meter) \\
\hline United Arab Emirates & 6.43 & 3.5 & 50.2 & 58.1 \\
\hline Qatar & 25.46 & 13.8 & 76.6 & 19.8 \\
\hline Bahrain & 0.09 & - & 13.4 & - \\
\hline Oman & 0.98 & 0.5 & 24.1 & - \\
\hline Total area of Persian gulf & 57.09 & 40.6 & - & 286.4 \\
\hline
\end{tabular}

Table 3. Revenues of crude oil export in Persian Gulf countries

\begin{tabular}{|c|c|c|c|c|c|c|c|c|}
\hline Country & Saudi Arabia & Iraq & UAE & Kuwait & Nigeria & Angola & Venezuela & Iran \\
\hline $\begin{array}{l}\text { Revenue from oil sale } \\
\text { Billion dollars }\end{array}$ & 321723 & 89402 & 126307 & 108482 & 89314 & 67861 & 85829 & 61923 \\
\hline Percent of OPEC sale & 29 & 8 & 11.5 & 9.9 & 7.8 & 6.5 & 7 & 6 \\
\hline
\end{tabular}

Reference: statistical annual bulletin of OPEC, 2013

\section{Iran Position in Energy Supply}

Iran has 137 billion barrels (12\%) of global proved oil reserves which is in second place after Saudi Arabia. Also, 27 trillion cubic mere (15\%) of global gas reserves are in Iranian hand that is in the second place after Russia. Islamic republic of Iran produces 4 million barrels per day of oil daily and 120 billion cubic meters annually has $4 \%$ and 5\% of global oil and gas production respectively. The position of Iran, particularly in gas sector, has more importance due to the fact that gas has obtained an especial position in the strategy of energy security of Asian consumers. Additionally, Iran has the second largest global gas resources and a superior geographical circumstance in western of Asia. The independent Iran policy in its energy resources management, permanent stability in politics and its interest in the cooperation with Asian countries extends its capacities in order to make and consolidate Asian integration (19).

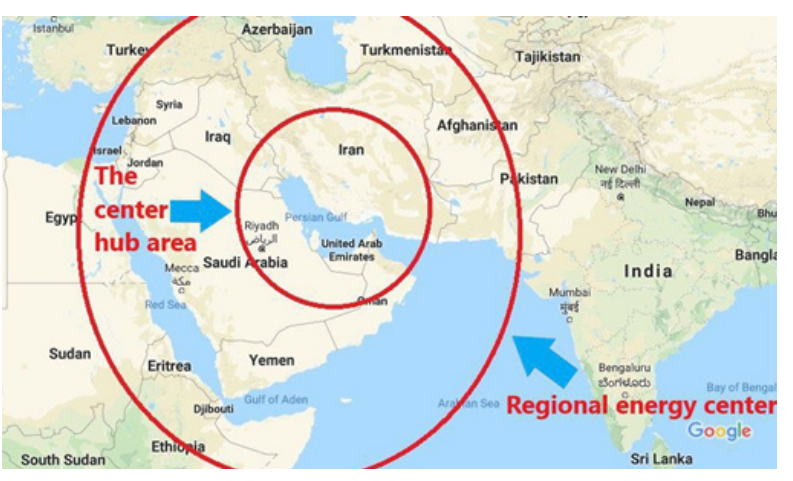

Figure 1. The position of Iran in energy ellipse.

As it can be seen in the map, Iran is based in the center of strategic energy ellipse (gas and oil). Moreover, this region is the heart of three continents of Asia, Europe, and Africa junction. While Iran as one of the most significant energy producers in the world has an indicative role in the global energy security level. It has 138.4 billion barrels of oil which is counted as 11.2 percent of global oil reserves (Table 3 ).

Table 3. Reserves, production, and age of crude oil reserves in Iran (January, 2009)

\begin{tabular}{|l|c|c|c|c|c|c|c|}
\hline $\begin{array}{l}\text { Iran/reserve at the end } \\
\text { of the year }\end{array}$ & 1987 & 1997 & 2005 & 2009 & 2008 & $\begin{array}{c}\text { Percent of global } \\
\text { reserves }\end{array}$ & $\begin{array}{c}\text { reserves age to } \\
\text { production }\end{array}$ \\
\hline $\begin{array}{l}\text { Crude oil } \\
\text { Million barrels }\end{array}$ & 92.9 & 92.6 & 137.5 & 138.4 & $1 / 4$ & 11.2 & 86.9 \\
\hline
\end{tabular}

Reference: BP 2008, P6

Table 4. Natural reserves of Iran 1986-2009

\begin{tabular}{|l|c|c|c|c|c|c|c|}
\hline $\begin{array}{l}\text { Iran/ reserves at the end of } \\
\text { the year }\end{array}$ & 1986 & 1996 & 2005 & 2009 & $\begin{array}{c}\text { Production at } \\
\text { the end of 2008 }\end{array}$ & $\begin{array}{c}\text { Percent of global } \\
\text { reserves }\end{array}$ & $\begin{array}{c}\text { Reserves age (reserve } \\
\text { to production) }\end{array}$ \\
\hline $\begin{array}{l}\text { Natural gas (trillion cubic } \\
\text { meter) }\end{array}$ & 13.96 & 23.0 & 27.58 & 1045.7 & 116.3 & 16.0 & More than 100 years \\
\hline
\end{tabular}

Reference: BP 2008, P22. EIA.2009.PP46 
Table 5. Reserves, production and age of crude oil reserves and natural gas of Iran 2012

\begin{tabular}{|c|c|c|c|c|c|c|c|c|}
\hline $\begin{array}{l}\text { Iran/ Reserves at the end of the } \\
\text { year }\end{array}$ & 1997 & 2005 & 2008 & 2010 & 2012 & 2010 & $\begin{array}{l}\text { Percent of global } \\
\text { reserves }\end{array}$ & reserves age \\
\hline $\begin{array}{l}\text { Crude oil } \\
\text { Million barrels perp day }\end{array}$ & 926 & 1375 & 1384 & 1376 & 1512 & 4321 & 9.1 & 95.8years \\
\hline Natural gas (trillion cubic meter) & 1396 & 230 & 2758 & 2961 & 11686 & 1518 & 159 & $\begin{array}{l}\text { More than } 100 \\
\text { years }\end{array}$ \\
\hline
\end{tabular}

Reference: BP2012, oil and gas, annual report

\section{Geopolitical Position of Iran}

Power of each country strongly depends on its geopolitics and geography in the political geographer point of view. Regarding its geographical situation, Iran has a unique geopolitical condition. This leaded to be the reason for Iran to be an international country which has an outstanding role in global equations ${ }^{13}$.

Sothern beach of Iran is $1375 \mathrm{~km}$ in length. This is counted as the most important communication center of world, Europe continent, south Asia, and Southeast Asia (Energy and Industry 2007, 90).

Additionally, Iran is based in the center of 72 percent of global oil and gas reserves. Iran is the most important highway for transferring energy and regional and/or international trade development in goods and energy trade point of view. On the other hand, Iran is neighbor with Iraq, Turkey, Pakistan, and Afghanistan in east and west. Considering Persian Gulf countries, it borders 15 countries via Maritime and terrestrial borders. Thus, Iran has been called east to west terminal since years ago. Also, neighboring countries map shows that Iran soil is the easiest way to reach international free waters or it is Persian Gulf or Hormouz Strait which is the only way (www. qeshm.ir).

\section{Analysis of Transportation and Energy Transit Corridors and Position of Iran}

The objective of every convergent corridor is to develop cooperation in trade and economy of regional countries in which billions of dollars goods and services are exchanged daily. It is by the use of these corridors that makes every country selfdependent via free trade ${ }^{14}$.

According to UN experts announcement in international transportation affairs, it is two corridor which passes through Iran out of three corridors.

1. Western/eastern corridor, abilities and potentials Chabahar port in southeast corner of Iran is the most south corridor of west/east in global trades and it is the best economic way to transit goods to Afghanistan, shortest way for Middle Asia to reach free waters, connection to the land. Possibility of fuel station construction and other international floating services and also extensive ability for related activities are the most distinguished abilities. Chabahar region due to being out of Persian Gulf, is the nearest port of country to international waters. It is also the only beach of Iran with accessibility of ocean and the most south passing point of east to west corridor in the wolrld.

2. North/south corridor, abilities and potentials

This corridor connects India to central Asia countries and gains considerable revenue for Iranians. Transportation per a container through this way is 30 percent cheaper than current way (Red sea, Suez channel and Mediterranean Sea). Furthermore, its time becomes 50 percent less than current way. The main objective of this corridor which its contract was signed in September 2000 was to grow transportation connections between countries signed the contract (Iran, India, and Russia) and the other countries ${ }^{15}$.

\section{Abilities and Potentials of Iran Transit in Central Asia}

One of unproven initial resources is oil reserve (with a less importance, gas) in the area near to Persian Gulf which is Caspian Sea. This area is complementary of Persian Gulf oil potentially. However, the political and economic issues of oil and gas transportation to the market are not resolved yet. Three oil and gas producers of this area which are Azerbaijan, Kazakhstan, and Turkmenistan cannot deliver their products to the market. These are a consequence of very sensitive geopolitics ${ }^{16}$.

The only way of these countries to transport oil and gas was the Russian pipeline in the past. By Soviet Union collapse, these countries decided not to be dependent on Russia. As a consequence, transportation of oil and gas has become a very severe issue for these countries that are Kazakhstan, Azerbaijan, and Turkmenistan ${ }^{17}$.

Therefore, these countries are isolated from potential large markets physically. They are completely onshore with no access to international transit system. On the other side, the countries with pipeline passing through them catch high transit revenue. 
Furthermore, the pipeline means to access oil and gas. Transit pipeline construction also gives the power and intrusion upon oil stream. Moreover, oil companies want to transit energy to the international markets in a cheaper and more secure way. Lots of potential ways such as Georgia, Turkey, and Russia are unsecure politically and militarily.

This issue caused Iran to have a well position as cheapest, shortest, and the most proper way of energy resources transit of Caspian Sea. The available pipeline and prepared facilities in Iran are a cheap way for Caspian producers. Additionally, Persian Gulf ports of Iran are the nearest way to export oil to Southeast Asia as a growing market. These impacts and created opportunities for Islamic Republic of Iran are summarized as following:

The contract of pipeline construction in the beach of Caspian Sea was signed by three countries of Turkmenistan, Russia, and Kazakhstan which makes a severe weakness in Trans pipeline (supported by west) which was supposed to transmit energy in deep waters of Caspian Sea. It can be analyzed in this way that US intrusion in Caspian Sea equation has been damaged. So, the possibility of US intervention in the area to determine conditions of Caspian Sea as a third country has been fallen considerably. This is one of Iran benefits of signing this energy contract. Regarding the weakening of Trans project in Caspian Sea and transit position of Republic of Azerbaijan which was expected to transport Turkmenistan gas, the influence of Iran over Turkmenistan energy export increases. Iran which is one of Turkmenistan gateway of energy, will have amore impact on Turkmenistan policies and it will gain the possibility of increase in gas delivery and its transit through Iran pass.

The abilities and potentials of Iran transit in Black sea countries

Meanwhile, transportation of oil and gas of Iran to Black Sea countries is one of the cases which can be investigated. This connection with Black Sea is possible through Republics of Nakhjavan, Armenia and Georgia or through only republics of Armenia and Georgia. So, all countries in Black Sea including Bulgaria, Moldavia, and Georgia can receive Iran oil and gas through Batoom port in Georgia alongside Black Sea beach via selecting each one of these passes.

In fact, Iran would be a bridge that can export its oil considering location priority of consumer countries and selecting the shortest way from two origins of Persian Gulf and Black Sea. On the hand, oil exporter countries must use Iran pass in order to their oil transportation.

Abilities and potentials of energy transportation from Iran in the region of Persian Gulf

Due to its strategic position, in addition to have second and the first position in oil and gas reserves, Iran has the best ways of transporting energies of oil and gas from exporters to con- sumers. One of these routes is Strait of Hormoz that connects Persian Gulf to Indian Ocean through Oman Sea ${ }^{17}$.

Without Iran, Persian Gulf would lose lots of its abilities to export energy resources to the world. By having more than $2000 \mathrm{~km}$ of beach from Arvand to Gwatrport, in addition to dominance over water ways ending to Indian Ocean, Iran is the only country which can transport Persian Gulf resources to various parts of the world through the land. Furthermore, the most significant gas pipelines in Persian Gulf is Iran pipeline to Pakistan and India which transports 90 million cubic meters of gas to Pakistan daily. According to rising need of India to energy for initiating and continuing its economic activities, this country requires to import Iran gas. This route is 2700 $\mathrm{km}$ in length. Regarding the near land borders, it is believed that China knows Iran as the shortest route to hydrocarbon resources. It is because energy pipelines should pass through Afghanistan after leaving Iran to reach China ${ }^{18}$. Thus, considering mentioned points, it can be said that Iran is certainly the most important and precious highway for transporting energy and in fact, Iran is a highway of energy transportation.

\section{Results}

Nowadays as energy has gain a decisive role in national and international politics, it has created patterns of competition, cooperation, conflict, violation, interaction, convergence, and divergence in the global arena. Among all, Persian Gulf has a unique and special condition due to the fact that it has 65 percent of oil resources and almost 40 percent of natural gas resources of the world. It is believed to be the largest storage of global oil; accordingly, it has an important role in global equations currently and in the future ${ }^{19}$.

Currently in the Islamic Republic of Iran, one of the significant scenes which has capability and capacity of transforming to a social opportunity is interaction and cooperation in oil industry. Growing need of energy especially oil and gas on one hand and main concentration of these resources in Iran on the other side is indicative that Iran is yet center of energy policy of countries.

Owing to the fact that industrial countries, large economic powers and also emerging powers has a considerable share of total energy consumption and this amount of energy consumption is increasing, so energy resources, energy security, and diplomacy of energy captures more importance for actors. In the energy market, Iran as one of richest countries of oil and gas resources in Persian Gulf requires to determine energy consumer's policies especially large economic powers and also emerging powers. Moreover, it needs to identify the difference of directions and to investigate prospects in this context. It must be taken into account that the most important chapter between Iran economy and global economy is energy. 
Iran is based in the center of energy ellipse (oil and gas). Additionally, Iran has a fair superiority in the market of trade and transit woing to be among three continents of Asia, Europe, and Africa and it can become an important business hub through Institutionalization and making multi-aspect infrastructures of transportation ${ }^{20}$.

Iran superior position for energy transport improves when many of neighboring countries as main consumers of Persian Gulf oil and gas, focus on Iran in order to use these resources. It is due to the fact that Iran has the most secure and nearest routes to energy resources. Its route is the most proper in the aspect of natural disasters and saving money and time and also industry security.

In fact, Iran would be a bridge that can export its oil considering location priority of consumer countries and selecting the shortest way from two origins of Persian Gulf and Black Sea. On the hand, oil exporter countries must use Iran pass in order to their oil transportation. It should be mentioned that in addition to Iran oil and gas transit from south to north and northwest that is connected to Batoom port through Iran border of provinces of western and eastern Azerbaijan increases Iran importance for transporting energy. The Iran route of gas and oil from northeast of Iran to central Asia countries confirms the validity of Iran in transport sector ${ }^{21}$. Certainly, it can be said that Iran is the most important and worthy highway in transporting of energy.

However, if Iran cannot use this unique opportunity, it faces with many problems owing to the fact that US tries to isolate Iran politically and economically by all tools in hand. It is because energy transit from Iran makes this country to modify its geopolitical position and geoeconomy that this is against US objective.

\section{Reference}

1. Abutalebi M. Oil and gas transmission pipelines in Central Asia. Quarterly Journal of Central Asia and Caucasus Studies. 2008: 25 .

2. Ahmadi S and Mousavi E. The Role of Fossil Energy in Global Energy Geopolitics. Quarterly Journal of Rahbordeh Yas. 2008; 7.

3. Akhbari M. The strategy of West is to undermine the geopolitical power of the world of Islam. Resalat. 2006

4. Akhbari M. Geopolitical structure of the world and its impact on the Middle East. Articles of the First Scientific Congress of Iranian Association of Geopolitics. Tehran: Geographic Organization. 2004.
5. Azari M, Ebrahimi I. Middle East energy outlook and economic security of the Islamic Republic of Iran. Tehran: Tadbir Institute of Economic Research. 2007.

6. Amir Ahmadi H. Iran, US economic sanctions, and a particular viewpoint. Gozaresh Journal. 1995; 53.

7. Amir Ahmadian B. The formation of a new geostrategic era in Asia. Quarterly Journal of Central Asia and Caucasus Studies. 2005; 14(52).

8. Hafeznia M. Principles and concept of Geopolitics. Mashhad: Papoli. 2006

9. Hafeznia M. Geopolitics of Iran in the world of post-Cold War. Article in the Congress of Geography (Defensive and Security Applications), University of Imam Hussein Defense Science Research Center. 2000.

10. Odell P. Oil and World Power. Third Edition. Tehran: Kharazmi. 1996. PMCid:PMC2074629

11. Bagheri A. Investigating OPEC economic behavior regarding fifty years of performance and future developments of this organization within the framework of global energy market changes. A thesis of Ph.D. in Economics, University of Imam Sadiq. 2011.

12. Behrouzifar M. The effects of US unilateral sanctions on business economics of this country and global energy markets. Quarterly Journal of Trade Studies. 2004; 33.

13. Beheshti Dehkordi A. World energy outlook. Tehran: Institute for International Energy Studies. 2006

14. Sani Joushghani M. An approach to International Political Economy and the position of energy in Iran-US relations. Quarterly of Middle East Studies. 2010; 61.

15. Heshmatzadeh M. Darsi's wishes, the taste of Consortium. Zamaneh Quarterly. 2004; 3.

16. Kemp G, Harkavy R. Strategic Geography and the Changing Middle East. First and Second Edition. S. Hosseini Matin Trans. Tehran: Research Institute of Strategic Studies. 2004

17. Heidari M. Nabucco and energy security, regional and transregional actors. Quarterly Journal of Central Asia and Caucasus Studies. 2007; 66.

18. Khoshrou S. Challenges and consequences of Iran's oil sanctions. Energy Economics. 2011; 146 and 145.

19. Derakhshan M. Need of a new AppTek in Iran, Iraq, and Russia. Energy Economics. 2012; 149 and 150.

20. Sariolghalam M. The effects of the collapse of the Soviet Union on the Third World. Journal of Foreign Policy. Tehran: Political Studies. 1999; 4.

21. Shafa'i Q. Caspian Sea energy resources: Security support, development tools. Quarterly Journal of Central Asia and Caucasus Studies. 2002; 35.

22. Ezzati E. Cold peace and the status of Iran in the strategic developments. Negah Quarterly. 2009: 2(4). 